\title{
SAMPLING METHODS AND NUMBER OF ROUNDWOODS FOR DETERMINING THE MOISTURE CONTENT ${ }^{1}$
}

Danilo Barros Donato ${ }^{2 *}$, Renato Vinícius Oliveira Castro ${ }^{3}$, Angélica de Cássia Oliveira Carneiro ${ }^{4}$, Ana Márcia Macedo Ladeira Carvalho ${ }^{4}$, Benedito Rocha Vital ${ }^{4}$ and Rosimeire Cavalcante dos Santos ${ }^{5}$

\footnotetext{
${ }^{1}$ Received on 09.07.2014 accepted for publication on 26.06.2017.

${ }^{2}$ Universidade Federal de Viçosa, Doutor em Ciência Florestal, Viçosa, MG - Brasil. E-mail: <danilobdonato@hotmail.com>.

${ }^{3}$ Universidade Federal de São Joâo Del-Rei, Departamento de Ciências Agrárias, Sete Lagoas, MG - Brasil.E-mail: <castrorvo@ymail.com>.

${ }^{4}$ Universidade Federal de Viçosa, Departamento de Engenharia Florestal, Viçosa, MG - Brasil. E-mail: <cassiacarneiro1@gmail.com>,<ana.marcia@ufv.br>and <bvital@ufv.br>.

${ }^{5}$ Universidade Federal do Rio Grande do Norte, Unidade Especializada em Ciências Agrárias, Macaíba, RN - Brasil. E-mail: $<$ meire_caico@hotmail.com>.

*Corresponding author.
}

\begin{abstract}
This study had the objective of comparing two methodologies of sampling, Simple Random Sampling (ACS) and Stratified Random Sampling (ACE) to determine the optimum number of roundwood samples to obtain the moisture content of the population. In order to achieve this goal, different percentages of allowable error $(5,10,15$ and $20 \%)$ were considered for each sampling methodology. In the conduction of this study, the samples were randomly taken from a lot of 250 steres of wood, 144 roundwood of three meters of length and distributed in four classes of diameter. Later, the moisture content of these samples was determined. And, from these values, the population estimates (average, standard deviation, variance, coefficient of variation, and standard error) by ACS and ACE methods, helped to determine the optimum number of roundwood (n) to be sampled from different percentages of allowable error adopted in this study at $95 \%$ probability. According to the results, the amount of roundwood to be sampled from ACS for each allowable error 5, 10, 15 and $20 \%$ was respectively $214,55,25$ and 14 . For the ACE (proportional allocation) the amount of roundwood was $141,35,16$ and 9 for ACE (optimal allocation) this number was 136, 34, 15 and 8 . It was concluded that the most indicated sampling method for this study, considering the allowable error, was the ACE method.
\end{abstract}

Keywords: Simple casual sampling; Stratified casual sampling; Diameter class.

\section{MÉTODOS DE AMOSTRAGEM E NÚMERO DE TORAS DE MADEIRA PARA DETERMINAÇÃO DO TEOR DE UMIDADE}

\begin{abstract}
RESUMO - Este trabalho teve como objetivo comparar duas metodologias de amostragem, a amostragem casual simples (ACS) e a amostragem casual estratificada (ACE), com o propósito de determinar o número ótimo de amostras de madeira em tora para obter o teor de umidade da população. Foram consideradas diferentes porcentagens de erro admissivel (5, 10, 15 e 20\%) para cada metodologia de amostragem. Na condução do trabalho foram amostradas aleatoriamente, de um lote de 250 st de madeira, 144 toras e distribuidas em quatro classes de diâmetro. Em seguida, determinou-se o teor de umidade dessas amostras, e a partir desses valores foram calculadas as estimativas populacionais (média, desvio-padrão, variância, coeficiente de variação e erro-padrão) pela ACS e pela ACE, determinando assim o número ótimo de toras (n) a serem amostradas nas diferentes porcentagens do erro admissivel adotadas neste estudo, a 95\% de probabilidade. De acordo com os resultados, o número de toras a serem amostradas pela ACS para cada erro admissível 5, 10, 15 e 20\% foi, respectivamente, 214, 55, 25 e 14 toras; para a ACE (proporcional) foi 141, 35, 16 e 9; e para ACE (ótima) foi 136, 34, 15 e 8. Concluiu-se que o método de amostragem mais indicado para este estudo, considerando um mesmo erro admissivel, foi a ACE.
\end{abstract}

Palavras-Chave: Amostragem casual simples; Amostragem casual estratificada; Classe de diametro. 


\section{INTRODUCTION}

The sustainable use of wood as a raw material for cellulose, charcoal, timber, and other products consist in the standardization of its properties for a better conversion into a final product. The moisture content is one of the principal wood characteristics, and its control during the wood drying process is essential to guarantee a great utilization and applicability for the consumers, such as the wood charcoal producers (Vital et al., 1985). During industrial processing of roundwood, where there is a large volume of wood per lot, it is necessary to use a sampling method which assures that the moisture content of the samples represents with precision the amount of water of the whole allotment.

Thus, the determination of the moisture content is crucial to obtain the optimal cost/benefit relationship, and consequently, to guide the wood companies in the decision-making process of the final products, mainly during the industrial procedures that require a large volume of roundwood.

As the volume of roundwood in the industrial processes is huge, it is important to define the number of samples needed to find the moisture content. The number of samples depends on the final use of the wood, the resources available, the desired precision, the variability of the wood characteristic that is being measured, the sampling method, and the distribution of the sample units, as described by Soares et al. (2011).

According to Campos and Leite (2013), there are two criteria to determine the size of the sample. The first criterion relates to the percentage of the population area that is being sampled. In this case, it is not possible to establish a previous precision of the sample, as the error is only disclosed after the conclusion. The second criterion uses a sampling error that is prior established in a certain significant level of probability. This criterion is defined as the optimal method of sampling, as the number of samples is compatible to the maximum sampling error which was prior established.

The precision of a sampling size of the roundwoods to obtain the average moisture content is extremely important for the final use of the wood, especially when it is necessary to control this variable. In most of the cases, the calculations are not very trustful, being constantly underestimated for not use the proper sampling, especially when considering the diameter class, which has a significant influence on the drying process and consequently in the moisture content.

The general objective of this research is to compare two sampling methods (simple random sampling and stratified random sampling) and be able to define the optimal number of roundwood samples in a stere of wood to determine the moisture content. The specific objective is to evaluate different percentages of the allowable error $(5,10,15$, and $20 \%)$ for each sampling method.

\section{MATERIALAND METHODS}

This study randomly sampled 144 roundwoods from a population of 250 steres of Eucalyptus sp. wood (4,639 roundwoods). The trees were six years old, with a spacing of 2 meters by 3 meters, from the forest stands of Gerdau Florestal S.A. in the city of Três Marias, Minas Gerais State, Brazil.

The roundwood samples had three meters of length, and they were classified into four diameter classes (8-11,11-14,14-17, and 17-20 centimeters). The determination of the moisture content of each roundwood from the sampling was according to the ABNT NBR 14929 (ABNT, 2003)

Two probabilistic methods of selection and distribution were used to calculate the sampling units. The sampling was analyzed with the same probability of the sampling units, with simple random sampling (ACS) and stratified random sampling (ACE).

First, using the sampling theory, the optimal number of roundwood samples was estimated through ACS and ACE to determine the moisture content of the population. The goal was to find a value that represents the real amount of moisture in the roundwood. The sampling values were tested, considering the allowable percentage error $(5,10,15$, and $20 \%)$, with a $95 \%$ level of probability. The software Microsoft Excel was used to do the data analysis.

To calculate the number of roundwood samples to find the moisture content was established a finite population, as the total number of roundwood was known. In the ACS method, the values of average moisture content, variance, standard deviation, standard error, coefficient of variation, sampling error, confidence level, and the number of samples for errors and probability were calculated.

Revista Árvore. 2018;42(4):e420401

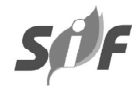


The population estimates in the ACS were calculated according to Soares et al. (2011), and they are showed in Table 1 .
Due to a significant heterogeneity in the diameter classes of the roundwoods and the different moisture content gradients, there was also an analysis of the

Table 1 - Equations used to calculate the population estimators of simple random sampling and stratified random sampling. Tabela 1 - Fórmulas utilizadas para os cálculos dos estimadores populacionais da amostragem casual simples e da amostragem casual estratificada

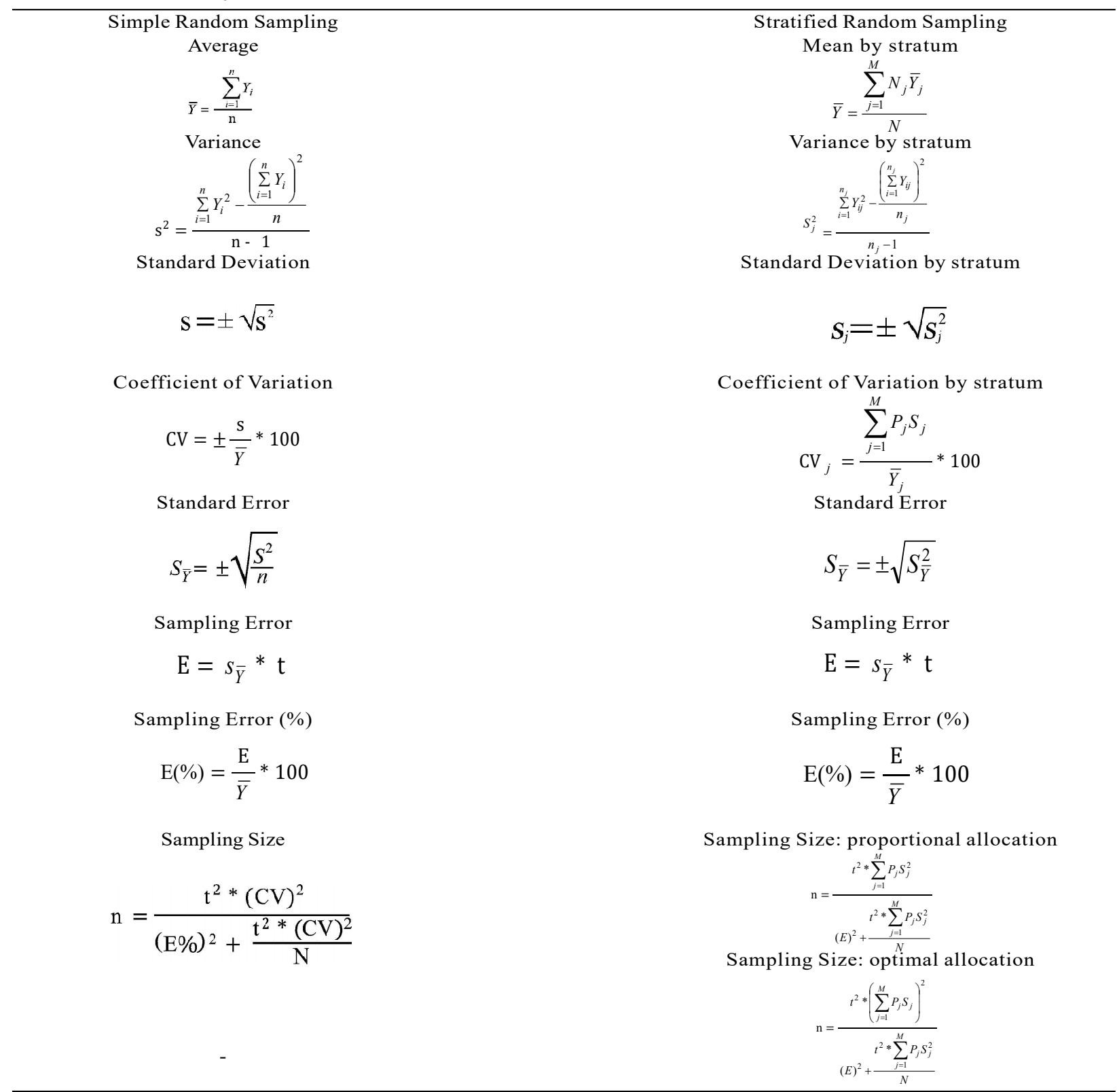

Where $\mathrm{n}=$ sampling size; $\mathrm{E}=$ allowable sampling error; $\mathrm{S}^{2}=$ variance of the characteristics observed in the sampling units; $\mathrm{N}=$ total number of sampling units; $Y=$ variable of interest (roundwood); $\mathrm{CV}=$ coefficient of variation; $\mathrm{s}=$ standard deviation; $\mathrm{S} y=$ standard error; and $\mathrm{t}=$ " $\mathrm{t}$ " table value from Student's $\mathrm{t}$-distribution statistics, at a significance level (á) and $n-1$ degrees of freedom. 
results using the ACE method that accounted the diameter class as different strata in this study. In the ACE method, the variables estimated were the mean by stratum, stratified mean, stratified variance, standard error, and sampling error, as described in Table 1.

The ACE analysis was obtained through proportional and optimal allocation.

\section{RESULTS}

The frequency and the average volume values of the roundwood according to its diameter class were used in the analysis of the sampling methods (ACS and ACE), considering the quantitative aspects. Table 2 shows the results of the ACS and ACE estimates.

During the analysis of the sampling errors related to the both methods, the ACS results showed a value superior to the allowable error of $5 \%$, and it would be necessary to use more 70 roundwood samples, as illustrated in Figure 1.

In the ACE analysis, both proportional and optimal allocation were within the allowable error of $5 \%$, as shown in Figure 2.

The other allowable errors $(10,15$, and $20 \%)$ tested in this study for both sampling methods were matched, considering the initial sampling units.

The results obtained for each stratum on the ACE methods are presented in Table 3 .

\section{DISCUSSION}

Rachid and Couto (1999) and Alvarenga et al. (2010), also found the same results in inventories

Table 2 - Results of the estimates of simple random sampling and stratified random sampling.

Tabela 2 - Resultado das estimativas da amostragem casual simples e da amostragem casual estratificada.

\begin{tabular}{|c|c|c|}
\hline STATISTICS & ACS & $\mathrm{ACE}$ \\
\hline Total number of roundwoods $(\mathrm{N})$ & 4639 & 4639 \\
\hline Total number of sampling units ( $\mathrm{n}$ ) & 144 & 144 \\
\hline Number of roundwoods per stratum & - & 36 \\
\hline Average moisture content $(\%)$ & 61,84 & 56,88 \\
\hline t calculated & 1,98 & 1,98 \\
\hline Standard Error & 1,95 & 1,95 \\
\hline Sampling Error & 3,86 & 2,76 \\
\hline Sampling Error (\%) & 6,24 & 4,85 \\
\hline Coefficient of Variation (\%) & 37,88 & 29,47 \\
\hline Confidence interval of the mean & $61,84 \pm 3,86$ & $56,88 \pm 2,76$ \\
\hline
\end{tabular}

Revista Árvore. 2018;42(4):e420401

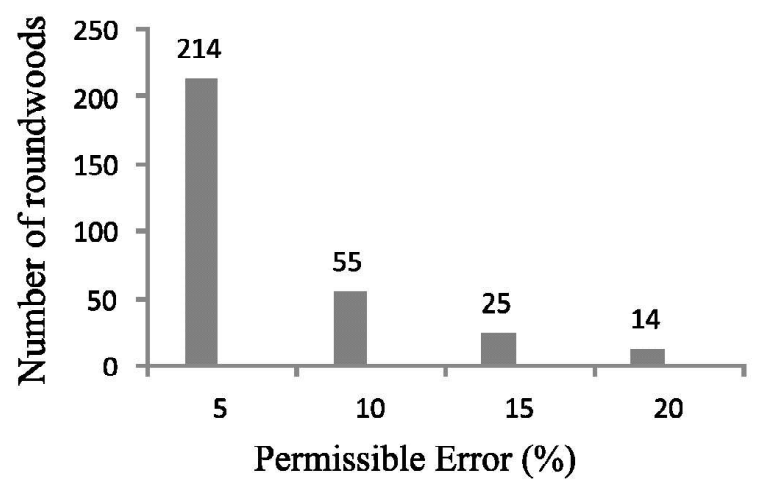

Figure 1 - Number of roundwoods per the allowable error (ACS).

Figura 1 -Número de toras por o erro admissível (ACS).

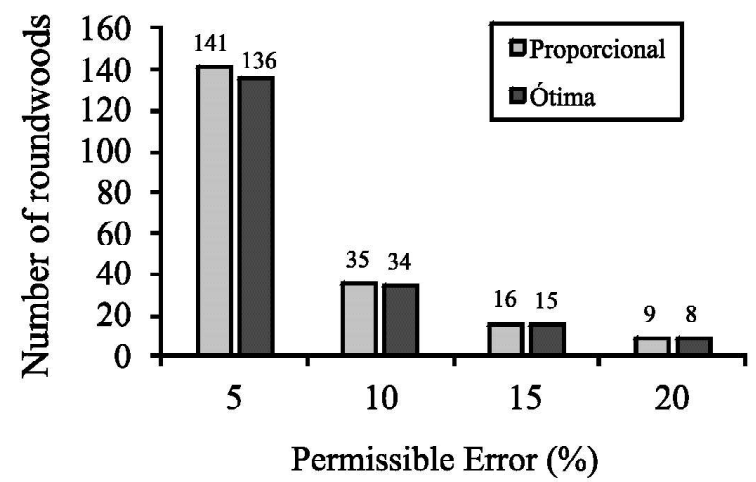

Figure 2 - Number of roundwoods per the allowable error (ACE).

Figura 2 - Número de toras por o erro admissivel ( $A C E)$.

during sampling comparison studies. These findings were already expected, as stratification reduces the variation sources, and consequently the sampling error. Each stratum is more homogenous than the forest stand.

However, the value of the allowable error in the ACE was lower than the ACS, which indicates a higher precision. The small variation around the average value in for the ACE level of confidence reinforces its superior efficiency compared to the ACS.

Once working with roundwood, there is a higher variation of diameters, that results in heterogeneity related to moisture content because of the diameter size that influences in the wood drying process. Then, roundwoods with a larger diameter have a higher moisture gradient than those with a smaller diameter. Chagas (2010) and Rezende et al. (2010), who performed studies 
Table 3 - Number of roundwoods to be sampled per stratum for ACE using the optimal allocation and proportional allocation.

Tabela 3 - Número de toras a serem amostradas por estrato para ACE utilizando a fixação ótima e a fixação proporcional.

\begin{tabular}{ccccc}
$\begin{array}{c}\text { Allowable } \\
\text { Error }\end{array}$ & Stratum & $\begin{array}{c}\text { Diameter } \\
\text { Class }(\mathrm{cm})\end{array}$ & $\begin{array}{c}\text { Optimal } \\
\text { Allocation }\end{array}$ & $\begin{array}{c}\text { Proportional } \\
\text { Allocation }\end{array}$ \\
\hline \multirow{3}{*}{$5 \%$} & 1 & $8-11$ & 28 & 38 \\
& 2 & $11-14$ & 67 & 69 \\
& 3 & $14-17$ & 33 & 26 \\
& 4 & $17-20$ & 8 & 8 \\
\hline \multirow{3}{*}{$10 \%$} & 1 & $8-11$ & 7 & 10 \\
& 2 & $11-14$ & 17 & 17 \\
& 3 & $14-17$ & 8 & 6 \\
& 4 & $17-20$ & 2 & 2 \\
\hline \multirow{3}{*}{$15 \%$} & 1 & $8-11$ & 3 & 4 \\
& 2 & $11-14$ & 7 & 8 \\
& 3 & $14-17$ & 4 & 3 \\
& 4 & $17-20$ & 1 & 1 \\
\hline \multirow{2}{*}{$20 \%$} & 1 & $8-11$ & 2 & 2 \\
& 2 & $11-14$ & 4 & 4 \\
& 3 & $14-17$ & 2 & 2 \\
\hline
\end{tabular}

about air drying wood, affirmed and concluded that the drying process is directly correlated to the diameter size. Therefore, it is clear that the ACE method is more needed than the ACS; besides the reduction in the roundwood diameter variability, it also increases the sampling precision, optimizes sampling costs, decreases the working time, due to the less sampling units needed when compared to the ACS method.

Table 3 shows that the ACE optimal allocation was more precise, as for the same sampling intensity it required fewer roundwood samples for each stratum than the proportional allocation. In the ACE method using proportional allocation, the number of elements in each stratum in proportional to the number of existing elements in each stratum, what does not consider the modification of the variable of interest, which in this study was the moisture content. The lower amount of roundwood samples needed on the ACE method using optimal allocation is because it considers in each stratum a number of elements which is proportional to the to the number of the existing elements in the stratum, and the variation of the variable of interest, measured by the standard deviation.

Although the increasing demand of roundwood use in the several companies in the forest sector, there is still no studies in the literature that have established the optimum sampling size of roundwood necessary to represent the real moisture content of the wood stacked in the yards, in the forest or the factories.

\section{CONCLUSION}

Both sampling methods, ACS and ACE, were appropriate to disclose the optimal quantity of roundwood samples to represent the average moisture content in a wood stack. However, there is a recommendation for the use of the ACE method with optimal allocation, as it shows a higher precision, and consequently, it requires a lower amount of roundwood samples.

The different percentages of the allowable error affect the forest logistics, considering practicality and economic facts.

It is recommended, for the calculation of the sampling intensity, to perform a study that evaluates until where it is feasible to execute a sampling with an allowable error that is lower or higher than the one which is in general used in the forest sector ( 10 to $15 \%$ ). Considering that the lower the allowable error to be used, the longer the time spent to perform the analyses, and consequently the higher the costs involved. On the other hand, the greater this error, the greater the chances of not making a correct sampling.

\section{ACKNOWLEDGEMENTS}

The authors would like to thank the Fundação de Amparo à Pesquisa do Estado de Minas Gerais (Foundation of Support to Research of Minas Gerais State) - FAPEMIG, the Secretaria de Estado, Ciência, Tecnologia e Ensino Superior (Secretary of State, Science, Technology and Higher Education) - SECTES/MG, the Conselho Nacional de Pesquisa e Desenvolvimento (National Council of Research and Development) - CNPq, and to the Grupo de Pesquisa de Carvão Vegetal (Research Group in Charchoal) - G6 for the financial support, especially the company Gerdau Florestal S.A.

\section{REFERENCES}

Alvarenga LH, Pinto ALR, Silva ST, Altoé TF, Morais VA, et al. Comparação de procedimentos de amostragem na precisão de Inventário florestal em fragmento de floresta estacional Semidecidual. In: Anais do $19^{\circ}$ Congresso de Pós-Graduação da UFLA; 2010. 
Associação Brasileira de Normas Técnicas ABNT. NBR 14929. Madeira - Determinação do teor de umidade de cavacos - Método por secagem em estufa.. Rio de Janeiro: 2003.

Campos JCC, Leite HG. Mensuração florestal: Perguntas e Respostas. Viçosa, MG: 2013. 407p.

Chagas L. Secagem da madeira para produção de carvão vegetal. Apresentação de slides do $2^{\circ}$ Fórum Nacional Sobre Carvão Vegetal. 2010.

Rachid CE, Couto HTZ. Estudo da eficiência de dois métodos de amostragem de árvores de rua na cidade de São Carlos - SP. Scientia Forestalis
1999(56):59-68.

Rezende RN, Lima JT, Paula LER, Faria ALR. Secagem ao ar livre de toras de Eucalyptus grandis em Lavras, MG. Cerne. 2010;16(Supl):41-47.

Soares CPB, Paula Neto F, Souza AL.

Dendrometria e inventário florestal. Viçosa, $\mathrm{MG}$ : UFV; 2011.

Vital BR, Della Lucia RM, Valente OF. Estimativa do teor de umidade de lenha para carvão em função do tempo de secagem. Revista Árvore. 1985;9:10-27.

Revista Árvore. 2018;42(4):e420401 